\title{
Gender Sensitivity at Judge's Verdicts in Samarinda and Magelang Religious Courts; The Implementation of PERMA Number 03 of 2017
}

\author{
Lilik Andar Yuni \\ Sharia Faculty IAIN Samarinda, Jl. H.A. M. Rifaddin Loa Janan Ilir, Samarinda, \\ Kalimantan Timur 75251 \\ Email: lilikandaryuni@yahoo.com \\ Murjani \\ Sharia Faculty IAIN Samarinda, Jl. H.A. M. Rifaddin Loa Janan Ilir, Samarinda, \\ Kalimantan Timur 75251 \\ Email:murjani@yahoo.com
}

Article history: Received: 14 November 2019, Accepted: 17 Juli 2020, Published: 28 December 2020

\begin{abstract}
:
Allegedly, some of judge's verdicts are gender-biased that it makes this an interesting research topic. This paper aims to observe gender sensitivity of judges' verdicts in Samarinda and Magelang Religious Courts as the implementation of PERMA Number 03 of 2017 during 2017-2019. As empirical normative legal research, this study used a qualitative descriptive method as the data analysis. The findings of research are: First, judges' verdicts, both in talā $q$ and divorce cases, in Magelang Religious Court showed very good gender sensitivity. The different condition occurred in talāq divorce verdicts at Samarinda Religious Court during 2017 and 2018 although in 2019, it showed a little improvement on gender sensitivity. However, verdicts of divorce lawsuit from 2017 to 2019 did not show likewise and it was very poor in gender sensitivity. Second, in Magelang Religious Court, PERMA Number 03 of 2017 had been very well implemented whereas in Samarinda Religious Court, it did not so as there found no much differences between verdicts before issuence of the PERMA and afterward.
\end{abstract}

Author correspondence email: lilikandaryuni@yahoo.com Available online at: http://ejournal.iainmadura.ac.id/index.php/alihkam/ Copyright (c) 2020 by al-ihkam. All Right Reserved 


\title{
Keywords:
}

Gender Sensitivity; Judges' Verdicts; PERMA Number 03 of 2017

\begin{abstract}
Abstrak:
Beberapa putusan hakim dinilai bias gender sehingga topik ini menjadi menarik untuk diteliti. Tulisan ini ingin mengkaji sensitivitas gender dalam putusan hakim di Pengadilan Agama Magelang dan Samarinda serta implementasi PERMA Nomor 03 Tahun 2017 selama 2017-2019. Sebagai penelitian hukum normatif empiris, tulisan ini menggunakan metode analisis data deskriptif kualitatif. Temuan penelitian adalah: Pertama, putusan hakim di Pengadilan Agama Magelang, baik dalam kasus cerai țalāq maupun cerai gugat, sudah menunjukkan sensitivitas gender yang sangat baik. Sementara itu untuk Pengadilan Agama Samarinda, putusan cerai țalāq pada 2017 dan 2018 tidaklah demikian meski ada sedikit kemajuan dalam hal sensitivitas gender pada putusan-putusan tahun 2019. Buruknya sensitivitas gender juga tampak di berbagai putusan cerai gugat di Pengadilan Agama Samarinda sejak 2017 sampai 2019. Kedua, PERMA Nomor 03 Tahun 2017 sudah terimplementasi dengan sangat baik di Pengadilan Agama Magelang. Namun demikian, hal yang sama tidak ditemukan di Pengadilan Agama Samarinda sebab keberadaan PERMA tersebut tidak berpengaruh signifikan terhadap putusanputusan yang dikeluarkan sebelum maupun sesudahnya.
\end{abstract}

Kata Kunci:

Sensitivitas Gender; Putusan Hakim; PERMA No. 03 Tahun 2017

\section{Introduction}

The dynamic of women's struggle for their rights encourages the enforcement of gender justice in all life aspects ranging from political, economic, social, to law. In the field of law, gender discrimination is allegedly found at three aspects, namely on the content of law, culture of law and the structure of law. The 
discrimination at the law structure is clear, among others, from the low gender sensitivity among law enforcement officers. ${ }^{1}$

The Religious Court (later abbreviated as RC) is one of the legal institutions which function to enforce various legislations. ${ }^{2}$ It deserves to receive, examine, adjudicate and resolve some Islamic sharia matters such as divorce which recently is getting higher and higher in number. Nationally, at the last 2018, the divorce cases in RC reached $97 \%$ of all cases. ${ }^{3}$ It rose from number at 2015 which still showed that $90 \%$ of 445,568 cases that the RC dealt with divorce. ${ }^{4}$

This high number is not automatically in line with gender sensitivity found at the judges' verdicts. Some judges' verdicts are still gender biased due to some reasons: First, educational background of judges which influences their mind-set and attitude. Second, value of patriarchy in family and social environment which exist in the miliue where the judges grow up; and third, the materials and legal rules which are, into some extent, still gender biased. ${ }^{5}$

Apart of those factors, the RC judges are essentially required to have sensitivity and concern on women in enforcing justice according to their authority. The active role of RC, meanwhile, is indispensable in order to influence matters relate to family law, especially related to women's rights. ${ }^{6}$

${ }^{1}$ Achie S. Luhulima et al., Perempuan dan Hukum: Menuju Hukum yang Berperspektif Kesetaraan dan Keadilan (Yayasan Pustaka Obor Indonesia, 2008), 131.

2Faqihuddin Abdul Kodir and Ummu Azizah Mukarnawati, Referensi bagi Hakim Peradilan Agama tentang Kekerasan dalam Rumah Tangga (Komnas Perempuan, 2008), 4.

${ }^{3}$ Cate Summer, Memberi Keadilan bagi Para Pencari Keadilan: Sebuah Laporan Penelitian tentang Akses dan Kesetaraan pada Pengadilan Negeri dan Pengadilan Agama di Indonesia Tahun 2007 - 2009 (Jakarta: Mahkamah Agung dan AUSAID), 7.

${ }^{4}$ Wahyu Widiana, "Prolog", in Kustini \& Ida Rosidah (ed.) Ketika Perempuan Bersikap: Tren Cerai Gugat Masyarakat Muslim (Jakarta: Kemenag RI, Badan Litbang dan Diklat: Puslitbang Kehidupan Keagamaan, 2016), ix.

${ }^{5}$ Ahmad Jalaludin, "Budaya Hukum Bias Gender Hakim Pengadilan Agama dalam Perkara Cerai Talak," Muwazah 7 (December 2015), 203.

${ }^{6}$ Defi Uswatun Hasanah, "Hak-Hak Perempuan dalam Putusan Pengadilan Agama (Studi Perbandingan Hukum Keluarga Islam dan 
Sensitivity on women's right is essentially required in order to establish a fair adjudication process. Therefore, judges are required to be prudent and wise in paying attention to the principle of gender equality living in the society, be it legal norm, religion, morality, and general social phenomenon while considering the consequences of verdicts they issue. ${ }^{7}$

Regarding to wife's rights after divorce, chapters 149 and 158 of Islamic Law Compilation (ILC) explicitly oblige the husband to give; (a) proper mut'ah; (b) living (nafqa), maskan (shelter) and kiswah (clothes) during `iddah (waiting) period; (c) settling owed dowry for wives and hadānah fees for children under 21 years old.

However, the article 41 letter (c) of Law number 1/1974 explains that the wife can not earn an 'iddah living if she is proven for doing $n u s h \bar{u} z$ (recalcitrance) or gets a $b \bar{a}$ 'in sughra divorce (irreconcilable ones). This unfortunately makes some RC, through their divorce verdicts, do not impose this obligations and ignore the right of wife although she is proved not doing any nush $\bar{u} z$.

Relating to this, Edi Riadi's study showed that the demand for 'iddah living more frequently found at talāq divorce cases than the divorce lawsuit one. From 156 talāq divorce cases as his sample, he mentioned that 81 cases or $51.92 \%$ of it filed for 'iddah living lawsuit. Meanwhile, there only found 45 of 146 divorce lawsuit cases with 'iddah living demand or 30.84 of the total number. ${ }^{8}$ In fact, the comparison between talāq divorce and divorce lawsuit rates was 1 out of 3. Based on national Badilag data from 2014, there were only 113,850 talā $q$ divorce cases while the divorce lawsuit cases were 268,381. ${ }^{9}$ A year ahead, at 2015, the talāq divorce number decreased to 99,981 cases and the rest of 253,862 were divorce lawsuit cases. Next at the

Konvensi CEDAW)," 2017, http://repository.uinjkt.ac.id/dspace/handle/123456789/38598.

${ }^{7}$ Siti Musdah Mulia, ed., Keadilan dan Kesetaraan Jender Perspektif Islam (Jakarta: Tim Pemberdayaan Perempuan Bidang agama Departemen Agama Republik Indonesia, 2001), 127.

${ }^{8}$ Edi Riadi, "Dinamika Putusan Mahkamah Agung Republik Indonesia dalam Bidang Perdata Islam," 2011, 199.

9Lilik Andaryuni, "Pemahaman Gender dan Tingginya Angka Cerai Gugat Di Pengadilan Agama Samarinda," Fenomena 9, no. 2 (December 1, 2017): 156-57, https://doi.org/10.21093/fj.v9i2.946. 
2016, the talāq divorce cases number got higher again at 113,968 while the divorce lawsuit cases were the same with 289,102 cases. As for 2017, the talāq divorce cases rose unsignificantly to 113,987 while the divroce lawsuit cases decreased to $273,771 .{ }^{10}$

Responding to the number, the Supreme Court has been making various efforts to ensure the rights of women after divorce enforced. Among of them are through the cassation verdict number 347 $\mathrm{k} / \mathrm{Ag} / 2010,410 \mathrm{k} / \mathrm{Ag} / 2010, \quad 137 \mathrm{k} / \mathrm{Ag} / 2007$ and number $276 \mathrm{k} / \mathrm{Ag} / 2010$. This jurisprudence provides legal power related to the provision of 'iddah living for divorce lawsuit case as long as the wife is officially proved for not doing nushüz. Nevertheless, not all Religious Courts implement it.

Not only that, in order to enhance efforts for improving the wives' rights after divorce, on July 11, 2017, the Supreme Court issued PERMA number 3 of 2017 on the guidelines for judging women in law cases. The article 6 of the PERMA explains the guidelines for judges to consider and to explore some values in ensure gender equality. The existence of the chapter is expected to bring out gender-responsive decisions or verdict. Therefore, this study was conducted particularly to examine whether existence of the PERMA affects in making a better accommodation for women's rights both in talāq divorce and divorce lawsuit.

One of RC with relatively high number of divorce is Samarinda $\mathrm{RC}$ with 1,706 lawsuit divorce cases last 2017.11 This number raises concerns especially related to the rights of wife and child after divorce. Another one is Magelang RC as the subject of a pilot project called PUG or Pengarusutamaan Gender covering gender mainstreaming as well as the rights of children and women since the beginning of 2017. The program itself is a cooperation between Kalijaga Institute for Justice (KIJ) and Badilag Supreme Court. Those factors become consideration to choose the two RC. Particularly for the later, this research wants to uncover whether the status as the

\footnotetext{
10"Melihat Tren Perceraian dan Dominasi Penyebabnya Hukumonline.Com," accessed December 9, 2019, https://www.hukumonline.com/berita/baca/lt5b1fb923cb04f/melihat-trenperceraian-dan-dominasi-penyebabnya/.

${ }^{11}$ Buku Laporan Tahunan Pengadilan Agama Samarinda Tahun 2017.
} 
subject of PUG pilot project influences the judges' verdicts on rights of women.

Studies on this theme have been many time taken by previous researchers. One of them was Nurcahaya et al who found that the implementation of the verdict on the wife's right after talā $q$ divorce in $\mathrm{RC}$ was generally done before recitation of the talā $q$ pledge. However, they underlined that the amount is relatively less than how the wives demand. ${ }^{12}$

Another study which focused on 'iddah living earning in the case of talāq raj' $i$ (reconcilable divorce) found that the wives generally do not get their rights if proved to do nushuzz. Nevertheless, the judge in South Jakarta Religious Courts provides the 'iddah living in the divorce lawsuit case on their initiative everytime the wives are proven not doing nush $\bar{u} z .^{13}$

Taking another focus, namely mut'ah and 'iddah right after țalāq divorce, a study by Alef Musyahadah et.al. found that judges generally consider gender sensitivity as clear from gender-unbiased verdicts. Almost all judges in Purwakarta RC, as they found, had good gender sensitivity as clear from the efforts in fulfilling the grant of $m u t^{\prime}$ ah and 'iddah living for wives. ${ }^{14}$

Those all studies show limited number of a specific study on gender sensitivity in judges' verdicts in relation to PERMA number 3 of 2017 on the guidelines for prosecuting women toward the law. Therefore, this study is conducted to complete the discussion on the discourse.

${ }^{12}$ Nurcahaya et al, "Studi Penegakan Hukum Hak-hak Harta Istri Cerai Talak( Analisis Gender Terhapa Realisasi Eksekusi Putusan Hak Nafkah dan Mut'ah Istri Cerai Talak di Pengadilan Agama", Laporan Penelitian Kompetitif Unggulan 2016, Universitas Islam Negeri Sumatera Utara Medan, 2016.

13Erwin Hikmatiar, "Nafkah Iddah pada Perkara Cerai Gugat," SALAM: Jurnal Sosial dan Budaya Syar'i 3, no. 2 (September 9, 2016), https://doi.org/10.15408/sjsbs.v3i1.3316.

${ }^{14}$ Alef Musyahadah Rahmah, Noor Asik, and Wismaningsih Wismaningsih, "Perspektif dan Sikap Hakim dalam Memutus Perksara Mut'ah dan Nafkah Iddah di Pengadilan Agama Purwokerto, Banyumas, Purbalingga," Prosiding 7, no. 1 (November 30, 2017), http://jurnal.lppm.unsoed.ac.id/ojs/index.php/Prosiding/article/view/49 3. 


\section{Research Method}

This study is empirical normative law research that considers the law as the norms of rules and regulations implemented at a certain time as a government product. ${ }^{15}$ The research itself examines judge's verdicts relying on documentation method while applying library study principles. The primary data come from legal materials, namely PERMA Number 03 of 2017, the verdicts of judges, KHI, and Law number 01 of 1974, while the secondary data are obtained from interview results with judges and information from several articles journals, and books with related themes. The tertiary one, on the other hand, is obtained from legal dictionary.

The data analysis uses a qualitative descriptive method as well as a legal approach. The later is particularly done by reviewing the rules on the specific issue of law that this study focuses on. Additionally, the court verdicts as the subject of this study were examined using a case approach. ${ }^{16}$

\section{Theoretical Framework of Gender Sensitivity, Judges' Verdicts and PERMA Number 03 of 2017}

Judges' gender sensitivity is defined as the ability to understand, feel, and think about the gaps in a men-women relationship. In this context, it is expected to be an alternative perspective in seeing injustice regarding with the relationship both in public and domestic areas. ${ }^{17}$

Meanwhile, the law of gender equality is much influenced by legal awareness as an integrated value in human being on existing laws or rules they expect to exist. ${ }^{18}$ In general scope, it also comes

\footnotetext{
15Peter Mahmud Marzuki, Penelitian Hukum (Jakarta: Kencana Prenada Media Group, 2009), 294.

16Peter Mahmud Marzuki, Penelitian..., 295.

${ }^{17}$ Abd. Moqsith Ghazali, Kumpulan Referensi Standar Evaluasi Hakim Dalam Menerapkan Sensitivitas Jender Di Mahkamah Syar'iyah Aceh, 2009, 119-21, //digilib.stital.ac.id/index.php?p=show_detail\&id=66.

${ }^{18}$ Soerjono Soekanto, Kesadaran Hukum \& Kepatuhan Hukum: Suatu Percobaan Penerapan Metode Yuridis-Empiris untuk Mengukur Kesadaran Hukum
} 
from society's legal culture so that to realize the gender-justice-based law, the legal culture that the society establishes is essentially needed. If the society's culture is gender-biased, the gender-justice laws will not be tangible.

On another hand, the judges' verdict is legal as a law material. ${ }^{19}$ Therefore, it is supposed to enforce the legal objectives namely justice, certainty and benefit. 20 Sudikno Mertokusumo defines the verdict of judges as an official authoritative statement by the judges pronounced before the trial in order to terminate or settle a case or dispute between parties. ${ }^{21}$

Unfortunately, as mentioned by Ninik Rahayu, gender sensitivity or justice has not been generally found in judges' verdicts because of these triggering factors. First, judges have not gotten any comprehensive understanding on gender-based violence or discrimination. Second, the die-hard patriarchy culture in the society which lowers women's bargaining values both in domestic and public areas. Third, the limitation of authority on behalf of law that makes the rights of women and children less considered.22

According to Artijo, as cited by Syamsudin, judges play a role as the main actor of law enforcement along with moral obligation and professional responsibility to control the common perception of people. They are supposed to master legal-technical capacity skills as well as show moral capacity. With good capabilities, including scientific and technical skills; the judges will be able to provide proper

dan Kepatuhan Hukum Mahasiswa Hukum terhadap Peraturan Lalu Lintas (Rajawali, 1982), 152.

${ }^{19 S}$ Sulistyowati Irianto and Lim Sing Meij, "Praktik Penegakan Hukum: Arena Penelitian Sosiolegal Yang Kaya," n.d., 212.

${ }^{20}$ Achmad Ali, Menguak Tabir Hukum: Ed.2 (Kencana, 2015), 96.

${ }^{21}$ Roihan A. Rasyid, Hukum Acara Peradilan Agama (Raja Grafindo Persada, 1991), 199.

${ }^{22 N i n i k ~ R a h a y u ~ M a k s o e m, ~ P e n a n g a n a n ~ H u k u m ~ Y a n g ~ " B e r p i h a k " ~ G u n a ~}$ Mewujudkan Kesetaraan dan Keadilan Gender", paper presented in A Day Seminar about Religious Court's Role and Civil Society in the Perspective of Islamic Law Pembaharuan di Bidang Penegakan HAM dan Penyetaraan Gender, Surabaya, PPHIMM PTA Surabaya, 24 Oktober 2014, 12. 
and correct legal reasoning in bringing in a verdict. ${ }^{23}$ In addition, as the main pillar of law enforcement, judges are also required to have sensitivity and concern on the elements of justice, tangible commitment, comprehensive understanding and courage for justice enforcement in every verdict they formulate. The Court's verdicts as the results of the judges' performance become the determinant of their quality and credibility because their crown or authority lies in the verdicts they issue. ${ }^{24}$ The judges are identical with the judiciary itself. ${ }^{25}$ In line with this, citing Friedman, Abu Tolhah explained that human are the important element of law enforcement. ${ }^{26}$

The basic adage also states that "all the law is judge-made law" which means that all the law basically comes from judges' verdicts. Moving on from this assumption, position of judges becomes very central in the context of law formation. ${ }^{27}$ Therefore, the judges' verdicts become law materials that must be in line with its own purpose namely justice, certainty, and benefit. 28

In practice, the three objectives of the law are difficult to achieve simultaneously at the judges' verdicts. There is often a collision between legal certainty and benefit, between justice and certainty, or between justice and benefit. Therefore, according to Radbruh, there needs to be a priority scale where the first rank is fairness followed by

${ }^{23}$ M. Syamsudin, "Keadilan Prosedural Dan Substantif Dalam Putusan Sengketa Tanah Magersari," Jurnal Yudisial vol. 7, No. 1 (March 24, 2014), 23, https://doi.org/10.29123/jy.v7i1.91.

24Zudan Arif Fakrulloh, "Penegakan Hukum Sebagai Peluang Menciptakan Keadilan," March 2005, 24, http:/ / publikasiilmiah.ums.ac.id/handle/11617/1034.

${ }^{25} \mathrm{Hj}$. Jamillah, "Judges According To Islamic Law and Indonesian Law in Islamic Court," IOSR Journal of Humanities and Social Science 22, no. 01 (January 2017), 91, https:/ / doi.org/10.9790/0837-2201068793.

${ }^{26} \mathrm{Abu}$ Tolhah, "Peluang dan Tantangan Kompetensi Peradilan Agama Pasca Amandemen Undang-Undang Nomor 7 Tahun 1989 Tentang Peradilan Agama," Asy-Syariah 18, No. 1 (August 31, 2015), p. 131, https://doi.org/10.15575/as.v18i1.654.

27Darji Darmodiharjo and Shidarta, Pokok-pokok Filsafat Hukum: Apa dan Bagaimana Filsafat Hukum Indonesia (Gramedia Pustaka Utama, 1995), 138.

${ }^{28}$ M.H, Menguak Tabir Hukum, 84-86. 
benefits and then certainty. Meanwhile, Achmad Ali recommends using a basic case priority adjusted to the context of each case. ${ }^{29}$

Relating to this, Mukti Arto mentions that as the verdict maker, judges should be able to be flexible by not too stick in the rule of the basic law in order the core of the benefit can be achieved in each verdict. The criteria of a qualified verdict in $\mathrm{RC}$, meanwhile, are: (1) well appointed, (2) systematic, (3) harmonious, and (4) indicating the renewal of Islamic law. ${ }^{30}$

PERMA Number 03 of 2017 on guidelines to prosecute women's cases dealing with the law comprises of 12 articles. It began its implementation since August 4, 2017. This PERMA explains the principle of judges in prosecuting women's cases dealing with the law, namely; (1) Appreciation for human dignity, (2) nondiscrimination, (3) gender equality, (4) equality toward the Law, (5) justice, and (6) benefits as well as legal certainty ${ }^{31}$

Meanwhile, the parameters of gender-sensitivity on judges' verdict regarding to the wive's rights after divorce are as follow;

a) Substantially, the law refers to; (1) Article $66 \mathrm{~S} / \mathrm{d} 86$ UU No. 7/1989, amended by Law No. 3/2006, the reamended by the Law number 50/2009; (2) Article $14 \mathrm{~S} /$ to $36 \mathrm{PP}$ number 9/1975 on the implementation of law number 1/1974; (3) Article 148 KHI on Presidential Decree number 1/1991; and (4) PERMA number 3/2017 on the guidelines for prosecuting women's cases against the law.

b) The judge's perspectives rely on the following principles; (1) maqāșid sharīah perspective use in order to protect weak parties; (2) divorce process which can be in divorce lawsuit, țalāq divorce or khul'i divorce; (3) each divorce causes separation between husband and wives then leads to different legal consequences; (4) negative effects of divorce mostly affect

${ }^{29}$ M.H, 96.

30Pustaka Pelajar, "Pembaruan Hukum Islam Melalui Putusan Hakim Pustaka Pelajar," 3, accessed November 23, 2019, https://pustakapelajar.co.id/buku/pembaruan-hukum-islam-melaluiputusan-hakim/.

31The article 2 PERMA Number 03 of 2017 on the guidelines on adjudicating women's cases on law. 
women and children; (5) making the verdict which grants mut'ah and 'iddah living either on the demands of wives or ex using ex-officio judges' right; (6) mediation procedure as an attempt to settle matters. ${ }^{32}$

\section{Gender Sensitivity in Judges Verdict}

1) Magelang Religious Court

The verdicts of talāq divorce in Magelang Religious Court are as follow:

\begin{tabular}{|c|c|c|}
\hline No. & Verdict number & Wives'/children's rights \\
\hline 1 & $\begin{array}{l}\text { No. } 89 / \text { Pdt.G/2017 in } \\
\text { verstek }\end{array}$ & $\begin{array}{l}\text { Punishing the plaintiff to } \\
\text { grant defendant as follow: } \\
\text { a.Mut'ah 1.000.000,- IDR } \\
\text { b.Children living Rp. } \\
\text { 300.000,- IDR/ month }\end{array}$ \\
\hline 2 & $\begin{array}{l}\text { No. 0113/Pdt.G/2017 in } \\
\text { verstek }\end{array}$ & $\begin{array}{l}\text { Punishing the plaintiff to } \\
\text { grant defendant as follow: } \\
\text { a. Mut'ah } 5.000 .000,- \text { IDR } \\
\text { b. Iddah living } 1.500 .000,- \\
\text { IDR }\end{array}$ \\
\hline 3 & No. 255/Pdt.G/2017 & $\begin{array}{l}\text { Punishing the plaintiff and } \\
\text { the defendant to obey the } \\
\text { peace agreement as follow: } \\
\text { a. The plaintiff grants 'iddah } \\
\text { living to the defendant } \\
6.000 .000,- \text { IDR } \\
\text { b. The plaintiff grants } \\
\text { defendant mut'ah in the } \\
\text { form of a gold ring } \\
\text { weighing } 10 \text { grams }\end{array}$ \\
\hline 4 & 046/Pdt.G/2018/PA.Mgl, & $\begin{array}{l}\text { Punishing the plaintiff and the } \\
\text { defendant to obey the } \\
\text { mediation agreement, which }\end{array}$ \\
\hline
\end{tabular}

32Siti Ruhaini Dzuhayatin et al., "Pedoman Modeling Institusionalisasi Proses Peradilan Responsif Gender, Hak Perempuan dan Hak Anak di Pengadilan Agama," n.d., 30-31. 


\begin{tabular}{|c|l|l|}
\hline & & $\begin{array}{l}\text { is to punish the plaintiff to } \\
\text { grant the defendant as follow: } \\
\text { a. Iddah living 2.100.000,- IDR } \\
\text { b. Mut'ah 1.000.000,- IDR } \\
\text { c. Each child is granted living. } \\
700.000,- \text { IDR/ month. }\end{array}$ \\
\hline 5 & 025/Pdt.G/2018/PA.Mgl & $\begin{array}{l}\text { Punishing the plaintiff and the } \\
\text { defendant to obey the } \\
\text { mediation agreement, which } \\
\text { is to punish the plaintiff to } \\
\text { grant the defendant as follow: } \\
\text { a. Iddah living 3.000.000,- } \\
\text { IDR } \\
\text { b. Mut'ah in the form of a } \\
\text { gold ring 75\% weighing 2 } \\
\text { grams }\end{array}$ \\
\hline 6 & $\begin{array}{l}\text { 258/Pdt.G/2017/PA.Mgl in } \\
\text { verstek }\end{array}$ & $\begin{array}{l}\text { Punishing the plaintiff to } \\
\text { grant the defendant as follow: } \\
\text { a. Mut'ah 3.000.000,- IDR } \\
\text { b. Iddah living 6.000.000,- IDR } \\
\text { c. Children living 2.000.000,- } \\
\text { IDR/ month }\end{array}$ \\
\hline
\end{tabular}

6 sample of tala $q$ divorce verdicts mentioned at the table, 3 cases from 2017 and 3 cases from 2018, makes it clear that wives get their rights after divorce, ranging from the provision of 'iddah living, mut'ah and also children's living. The amount and number, however, are not equal each others.

Interestingly, in some of those verdicts, wive's and children's rights are fulfilled in verstek cases, as seen in the verdict number 089/PDT. G/2017/PA. Mgl., number 0113/Pdt. G/2017/PA. Mgl., and number 258/Pdt. G/2017/PA.Mgl. The verdict of verstek is a verdict in which one party is absent even though she/he has been called appropriately and worthily and sending no one to represent. The verdicts also show that the grant for wives after divorce is through ex officio right.

The ex officio right, as Subekti disclosed, is the right because of position as a judge instead of because any assignation or promotion. 
It means that ex officio is automatically attached to the judge because of his/her position aiming to bring in verdicts of the case into decision more than what the plaintiff demands.

The use of ex officio rights as clear at the above verstek verdicts is based on the following considerations. First, the respondent (wife) was proved not doing nushüz. Second, it refers to the article 149 letter (a) and (b) KHI which confirms that after divorce, husband is obliged to provide living both for iddah and mut'ah as long as the wife is proven not doing nushīz. Mut'ah also aims to please her while reducing grief due to divorce. Third, the plaintiff (husband) has the ability and willingness to afford such rights. ${ }^{33}$

It is further explained that ex officio in those cases (talāq divorce in verstek) is given because most of the wives in those cases are illtreated. Unfortunately, the grant through ex officio is not always well fulfilled because the plaintiff sometimes has no enough money to afford. The most important of this procedure is to show that ex officio right intends to educate society that when women are divorced, they have rights to seek and grant. ${ }^{34}$

Conversely, if the parties are present at the trial, mediators should try hard to play their roles. Despite failing to reconcile the parties, the mediators are suppossed to manage in order to make a deal between both through an agreement which accommodates the rights of wife after divorce as shown in the verdict number 255/PDT. G/2017/PA. Mgl., number 046/Pdt. G/2018/PA. Mgl., and number 025/PDT. G/2018/PA. Mgl. In Magelang RC, the mediator is the judge himself/herself. He/she plays the role flexibly through explaining rights and obligations of each party on taläq divorce case. It is obvious, therefore, that the role of mediator is not merely seeking peace but also trying to lead the parties understand their rights. Consequently, the divorcee can access her right.

Meanwhile, the data on divorce lawsuit verdicts in Magelang RC during 2017-2018 is as follows;

\footnotetext{
33Interview with some judges of Magelang Religious Court, April 24, 2019. See the judge's consideration in the verdict No. 113/Pdt.G/2017/PA.Mgl.,

${ }^{34}$ Interview to the judges in Magelang RC, 24 April, 2019.
} 17. 


\begin{tabular}{|c|c|c|}
\hline No. & Verdict Number & Wives' / Children's Rights \\
\hline 1 & $\begin{array}{l}\text { No. } \\
\text { 076/Pdt.G/2017/PA.Mgl }\end{array}$ & $\begin{array}{l}\text { Punishing the defendant to } \\
\text { grant the plaintiff as follow: } \\
\text { a. Iddah living } 3.000 .000,- \\
\text { IDR } \\
\text { b. Mut'ah 5.000.000,- IDR }\end{array}$ \\
\hline 2 & $\begin{array}{l}\text { No. 94/Pdt.G/2018/ } \\
\text { PA.Mgl in verstek }\end{array}$ & $\begin{array}{l}\text { Assigning the custody of } \\
\text { children to the plaintiff }\end{array}$ \\
\hline 3 & $\begin{array}{l}\text { No. 098/Pdt.G/2018/ } \\
\text { PA.Mgl in verstek }\end{array}$ & $\begin{array}{l}\text { Assigning the custody of } \\
\text { children to the plaintiff }\end{array}$ \\
\hline 4 & $\begin{array}{l}\text { No. } \\
\text { 060/Pdt.G/2018/PA.Mgl }\end{array}$ & $\begin{array}{l}\text { a. Assigning the custody of } \\
\text { children to the plaintiff } \\
\text { b. Punishing the defendant } \\
\text { to give the children's } \\
\text { custody to the plaintiff. } \\
\text { c. Punishing the defendant } \\
\text { to grant children's living } \\
\text { 1.000.000,- IDR/ month. }\end{array}$ \\
\hline 5 & $\begin{array}{l}\text { No. } \\
\text { 015/Pdt.G/2018/PA.Mgl }\end{array}$ & $\begin{array}{l}\text { a. Assigning the custody of } \\
\text { children to the plaintiff } \\
\text { b. Punishing the defendant } \\
\text { to provide living for } \\
\text { children } 1.000 .000,- \\
\text { IDR/month }\end{array}$ \\
\hline 6 & $\begin{array}{l}\text { No. } \\
\text { 052/Pdt.G/2018/PA.Mgl in } \\
\text { verstek }\end{array}$ & $\begin{array}{l}\text { Assigning the custody of } \\
\text { children to the plaintiff }\end{array}$ \\
\hline
\end{tabular}

The table above explains that some of verdicts of divorce lawsuit in Magelang RC were made in verstek and some were not. Cases attended by the parties lead to a verdict that grants wives and children get their right. It can be seen in the verdict number 076/Pdt. G/2017/PA. Mgl., number 060/Pdt. G/2018/PA.MGL, and number 015/PDT. G/2018/PA. Mgl. In those verdicts, all parties were present which enabled the judge to do mediation although it did not lead to any deals. However, copies of the verdicts show that plaintiffs of the three verdicts are proven not doing nushuz so that 
the Court shall grant its ex officio right by referring to the considerations as follows;

For a case number 076/PDT. G/2017/PA. Mgl, the wife as the plaintiff did not require an 'iddah living and mut'ah. However, the article 41 (e) UU number 1/1974 Jo Article 149 (A and B) and MA jurisprudence number 137K/AG/2007 show that the wife who filed for the divorce and was proved not doing nushüz enables the judges to use ex officio right. Using this right, the judges can demand the husband to provide an 'iddah living for her wife because she must go thorugh the period of 'iddah. Furthermore, the MA jurisprudence number $02 \mathrm{~K} / \mathrm{AG} / 2002$ clearly mentions that even if not requested in the Court, the judge using ex officio right can impose the husband to provide 'iddah living and $m u t^{\prime}$ ' $a$ h to his wife. ${ }^{35}$

In addition to law materials as mentioned above, the verdict number 015/PDT. G/2018/PA. MGL is also reinforced by SEMA number 42016 on the implementation of the plenary meeting results formulation of Supreme Court and the formulation of the Religious Court. It states that RC through ex officio right can set a child's living to his/her father when he/she is under custody of the mother. ${ }^{36}$

The above explanation clarifies that the use of ex officio right provides more protection and benefits for wives and children. This is in line with Ibrahim's study concluding that ex officio right aims to accommodate women's rights after divorce in which husbands sometimes neglect them. ${ }^{37}$

As for another verdicts in verstek form, namely number 094/Pdt. G/2018/Pa. Mgl. and number 098/Pdt. G/2018/PA. Mgl., the plaintiffs (wife and children, in this case) did not get their rights. The wives only got custody of the child because it was they who filed for the divorce and during the trial process, the parties in dispute (the defendant or the husband) were not present.

\footnotetext{
${ }^{35}$ See the verdict No. 076/Pdt.G/2017/PA.Mgl, 27.

36See the verdict No. 015/Pdt.G/2018/PA.Mgl, 27.

37Ibrahim AR Ibrahim AR and Nasrullah Nasrullah, "Eksistensi Hak Ex Officio Hakim dalam Perkara Cerai Talak," SAMARAH: Jurnal Hukum Keluarga dan Hukum Islam 1, No. 2 (December 30, 2017): 463, https://doi.org/10.22373/sjhk.v1i2.2378.
} 
Meanwhile, most of the divorce case lawsuits are brought in a verdict by verstek due to various reasons such as because the defendant is in unknown address, deliberately leaving his wife, and other various reasons. In this condition, the husband tends not to attend the trial that it leads to verstek verdict. Another reason for a wife to file a divorce lawsuit is because the husband does not work and earn living. In this kind of case, it is very unlikely for the wives to get their rights after divorce such as 'iddah living and mut'ah because the husbands possibly cannot afford it.

2) Samarinda Religious Court

The verdicts of talāq divorce in Samarinda Religious Courts during 2017-2018 are as follow:

\begin{tabular}{|c|c|c|}
\hline No. & Verdict Number & Wives/Children's Rights \\
\hline 1 & 857/Pdt.G/2017/PA.Smd & $\begin{array}{l}\text { Punishing the reconvention } \\
\text { defendant to provide: } \\
\text { a. Living of 'iddah, } \\
\text { 9.000.000,- IDR } \\
\text { b. Mut'ah, } 6 \text { million,- IDR } \\
\text { c. Living for child, } \\
\text { 2.000.000,- IDR/month }\end{array}$ \\
\hline 2 & 1014/Pdt.G/2017/PA.Smd & $\begin{array}{l}\text { Punishing the reconvention } \\
\text { defendant to provide the } \\
\text { neglected living, 3.000.000,- } \\
\text { IDR and 'iddah living, } \\
\text { 3.000.000,- IDR }\end{array}$ \\
\hline 3 & 429/Pdt.G/2018/PA.Smd & - \\
\hline 4 & $\begin{array}{l}\text { 1843/Pdt.G/2018/PA.Smd, } \\
\text { in verstek }\end{array}$ & - \\
\hline 5 & 1694/Pdt.G/2018/PA.Smd & $\begin{array}{l}\text { Assigning child custody to } \\
\text { the defendant }\end{array}$ \\
\hline 6 & $\begin{array}{l}\text { 194/Pdt.G/2019/PA.Smd, } \\
\text { in verstek }\end{array}$ & $\begin{array}{l}\text { Punishing the plaintiff to } \\
\text { provide the defendant as } \\
\text { follow: } \\
\text { a. 'Iddah living } 3.000 .000 \text {,- } \\
\text { IDR } \\
\text { b. Mut'ah } 500.000,- \text { IDR }\end{array}$ \\
\hline
\end{tabular}




\begin{tabular}{|c|l|l|}
\hline & & $\begin{array}{l}\text { c. Hadhanah to the defendant } \\
\text { d. Child's living, 1.000.000,- } \\
\text { IDR/ month }\end{array}$ \\
\hline 7 & $\begin{array}{l}371 / \text { Pdt.G/2019/PA.Smd, } \\
\text { in verstek }\end{array}$ & $\begin{array}{l}\text { Punishing the plaintiff to } \\
\text { provide the defendant; } \\
\text { a. 'Iddah living, 6.000.000,- } \\
\text { IDR } \\
\text { b. Mut'ah, 2.000.000,- DIR }\end{array}$ \\
\hline
\end{tabular}

The table gives an overview on the wife's rights after divorce in țalāq divorce verdict at Samarinda RC. Among the mentioned examples, some of them were administered in verstek while others were with the presence of litigants. Three verdicts in non-verstek procedure came from cases in which the defendants were present at the trial and their rights after divorce were obtained.

Acquisition of the wives' rights, consisting of 'iddah living, mut'ah, and the child's living, comes from consideration on the condition in which from the beginning of process, they requested the rights through the reconvention. It means that defendant's knowledge and understanding on the rights they deserve are good enough.

The result of Mansari \& Moriyanti's study asserts that cases in which the judge does not grant the living right for wives is due to the wives themselves. They do not understand their own rights or simply accept their destiny while only focusing on the main purpose to gain divorce certificate. From the beginning of trial process, they actually do not want a divorce hoping that resolution can be achieved and the family unity can be rebuilt. Therefore, they do not sue any living at all. ${ }^{38}$

In more details, the case number 857/PDT. G/2017/PA. SMD portrayed a condition in which the defendant (wife) obtained her rights because she was accompanied by a lawyer. Meanwhile, the case number 1014/Pdt. G/2017/PA. SMD) did not enable the defendant to gain her rights because of her own insufficient knowledge and

${ }^{38}$ Mansari Mansari and Moriyanti Moriyanti, "Sensitivitas Hakim terhadap Perlindungan Nafkah Isteri Pasca Perceraian," Gender Equality: International Journal of Child and Gender Studies 5, no. 1 (October 14, 2019): 53-55, https://doi.org/10.22373/equality.v5i1.5377. 
understanding on what she deserves for. Moreover, she was not being accompanied by a lawyer during the trial.

Another case, namely number 429/PDT. G/2018/PA. SMD, also did not grant the wife's right even if she was present at the trial. It turned out that the wife did not request her rights in the reconvention. This is possibly due to her ignorance and for this kind of situation, the role of judges is particularly important. The judge needs to consider a principle that in order to reduce the divorce bad effect to wife and children, they need to get the rights whether they requested it or not. ${ }^{39}$ Additionally, the mandate of Article 149 letter (a) and (b) KHI also obliges him/her to tell this type of wife about what she deserves for. The wife, at this case, does not work and furthermore she lives with three children who still need living expenses..$^{40}$

The next case, a verdict in verstek form number 1843/Pdt. G/2018/PA. SMD did not grant the wife's rights due to another cause, which is the absence of the defendant at the trial. This indicates the absence of good etiquette from the wife. On the judge's side, the absence is also unexpected because it can impede him/her in confirming plaintiff's lawsuit materials. The judge will therefore get difficulties in granting the rights of wife in such conditions. ${ }^{41}$

Overall, samples from talāq divorce cases in 2017 and 2018 show that the talāq divorce in verstek form did not grant the wive's rights even if they attended the trial. On the contrary, in 2019, specially at the case number 194/PDT. G/2019/PA. SMD and number 371/PDT. G/2019/PA. SMD which were in the verstek forum, the wives gained their rights such as 'iddah, mut'ah, hadānah and child's living through ex officio right.

The use of ex officio right in the those verdicts issued in 2019 was with the following considerations; (1) The wives were proved not doing any nushizz, (2) The article 41 ACT number 1/1974 and article $149 \mathrm{KHI}$ (b) mention that due to divorce, a wife deserves for mut'ah and iddah living except if she is still virgin (qobla dukhūl), (3) The plaintiffs can afford the obligation, and (4) the existence of the

${ }^{39}$ Dzuhayatin et al., "Pedoman Modeling Institusionalisasi Proses Peradilan Responsif Gender, Hak Perempuan, Dan Hak Anak Di Pengadilan Agama," 30-31. ${ }^{40}$ See the verdict No. 429/Pdt.G/2018/PA.SMD, 5.

${ }^{41}$ Interview with a judge of Samarinda Religious Court, June 2019. 
jurisprudence of Supreme Court number 608K/AG/2003 dated March 25, 2003 and number 280K/AG/2004, dated November 10, 2004 concerning the range of the number of $i d d a h$ and $m u t^{\prime} a h .42$

In addition to it, referring to the principle of ex aequo et Bono, the Religious Court which argues otherwise than the lawsuit of a plaintiff can make the verdict as fair as possible. ${ }^{43}$ This clause makes it possible for judges to do ijtihad in order to make a justice-based verdict putting much benefit for the wife and child as the divorce victims. At the same time, it also asserted that the judge is not only a statute of law, but also the (representation of the) law itself because the verdict he/she makes becomes a legal product.

Following is the data of samples of divorce lawsuit verdicts in Samarinda Religious Court during 2017, 2018 and 2019.

\begin{tabular}{|c|l|c|}
\hline No. & \multicolumn{1}{|c|}{ Verdict Number } & Wives' /Children's rights \\
\hline 1 & $0580 /$ Pdt.G/2017/PA.Smd & - \\
\hline 2 & $30 /$ Pdt.G/2018/PA.Smd & - \\
\hline 3 & $1057 /$ Pdt.G/2019/PA.Smd, & - \\
\hline
\end{tabular}

On the contrary to talāq divorce cases in which the rights of wives and children are mostly fulfilled through either reconvention or the judge's ex officio right, the samples of divorce lawsuit cases show otherwise. Among 7 samples of lawsuit divorce verdicts taken either in form verstek or in the presence of litigants, such rights are nothing to obtain.

The condition when a wife filed the divorce lawsuit in the Religious Courts usually comes to these following models; (1) She knows her rights from a lawyer because accompanied by the legal authority during the trial process; (2) She knows her rights based on understanding and knowledge she has without the help of lawyer; (3) She knows her rights yet chooses not to demand it because she only focuses on one goal to get divorced while ignoring other issues, and (4) She doesn't know her rights at all that she proposed very minimum lawsuit, namely request for divorce.

${ }^{42}$ See the verdict No. 371/Pdt.G/2019/PA.SMD, 9.

${ }^{43}$ Interview with a judge of Samarinda Religious Court, July 2019 
The case number 580/PDT. G/2017/PA. SMD, for example, comes from a background that the plaintiff did not work and earn regular income, while the defendant was the chief of a government office, graduated from master degree and had two children. The copy of verdict mentioned that the cause of lawsuit divorce was because the husband had affair with another woman and used to be in anger when he was warned off not doing so.

The same cause for a divorce lawsuit was found at the case number 30/PDT. G/2018/PA. SMD. The plaintiff was a housewife with a child, while the defendant was the porter of online goods. Meanwhile, in the case number 1057/PDT. G/2019/PA. SMD, the plaintiff was a mother with 3 children whom works as private worker. Her husband, on another hand, had never given a living and only lazed around at home. When he was warned off not doing so, he used to be in anger. To be short, the plaintiff did not get her material rights that ensures her to file for divorce.

Another similarity among those three lawsuit divorce verdicts mentioned at the table was the wives' attitudes which were proven by not doing nushizz. Instead, they filed divorce lawsuit due to their husband's behavior such as having affair with another woman (number 580/PDT. G/2017/PA. SMD and number 30/PDT. G/2018/PA. SMD) and earning nothing for live expenses at the case number 1057/PDT. G/2019/PA. Smd.,. The verdict number 580/PDT. G/2017/PA. actually portrayed background in which the defendant (husband) worked as the head of one governmental offices in Samarinda and were S2 educated. In terms of wealth or material, it is obviously adequate to provide 'iddah and mut'ah living for his ex-wife compared to the verdict number 30/PDT. G/2018/PA. SMD where the defendant (husband) worked a porter of online goods. Unfortunately, those two got the same in term in obligation for fulfilling wives' rights after divorce.

In fact, when a wife was proven not doing $n u s h \bar{u} z$, referring to the article 41 ACT Number 1/9174, the Court, through the judge, can oblige a husband to give her the rights. The diction "can" becomes the base for the judge, with his ex officio, to force the husband to give the 
right even though it does not exist in the lawsuit.44 In such circumstance, the judge should be able to use the authority attached to him/her by granting rights for wife and children. She/he will then produce a justice values based verdict although the right is not sued by the plaintiff.

On the other hand, as divorce is included in civil law scope, one of its bases requires the judge not to impose any verdict outside the wishes of the parties (plaintiffs) or as known with the ultra petitum principle ${ }^{45}$ according to the mandate of Article 189 (3) RBg. This seems to be the reason for judges in Samarinda Religious Courts in making the verdict on divorce cases. When the plaintiff or wife just asked her divorce verdict while ignoring her rights, the judges just pronounced that.

In fact, a deeper observation shows that all wives engaged at the cases, either in verstek or not, were free from any nushüz suspicion. Therefore, ex officio right used at previously outlined cases should also been used in divorce cases, particularly when the husband can financially afford his obligation. This is also in line with the jurisprudence of MA Number 02K/AG/2002 mentioning that although not requested by the wife in her suit, judges through ex officio right can impose a husband to grant 'iddah and mut' ah living for the wife. Other jurisprudence materials as the legitimacy of granting the wife's rights after divorce as long as she were proven not doing nush $\bar{u} z$ are number $347 \mathrm{k} / \mathrm{Ag} / 2010,410 \mathrm{k} / \mathrm{Ag} / 2010,137 \mathrm{k} / \mathrm{Ag} / 2007$ and number $276 \mathrm{k} / \mathrm{Ag} / 2010$. If one of those things is made into consideration, the rights of the wife and child after divorce will be well accommodated.

\section{Data Analysis}

The sampling data from Magelang Religious Court vividly explained that the right of women and children after divorce are well

\footnotetext{
${ }^{44}$ Muhammad Aqwam Thariq, "Hak Ex Officio Hakim: Pertimbangan Hukum Hakim terhadap Pembebanan Nafkah Iddah dan Mut'ah dalam Perkara Cerai Talak Verstek Perspektif Maqashid Syariah (Kasus di Pengadilan Agama Kabupaten Malang)," n.d., 3.

${ }^{45}$ M. Yahya Harahap, Hukum Acara Perdata: Tentang Gugatan, Persidangan, Penyitaan, Pembuktian, dan Putusan Pengadilan (Sinar Grafika, 2005), 801.
} 
fulfilled both in talāq and divorce lawsuit. This, again, is due to chapters $149 \mathrm{KHI}$ and PERMA Number 03 of 2017. Additionally, the judges also considered more on the benefits and protection toward wives and children as the most suffering parties due to divorce. The husband, therefore, is obliged to provide living and mut'ah either over the suit of the wife or over the judge's ex officio and the optimal role of the mediator. Based on it, it can be fairly said that the verdicts of both țalāq divorce and divorce lawsuit in Magelang Religious Court show gender sensitivity because they have fulfilled the requirements as mentioned above. It even went the same way when the verdict was in verstek form because the judges used their ex officio right. In short, this certainly provides benefits and fairness for the wives and children

Granting the rights of wife and child in verstek verdict through ex officio right is highly recommended and useful as mentioned by a study of Muhammad Aqwam. He confirmed the advantages of using ex officio right in verstek and enlisted some following reasons: (1) As the defendant, most wives does not understand the law specifically the rights they deserve for. Therefore, when a husband filed a talāq divorce, she chose neither to attend the trial nore appoint a lawyer to be represent her; (2) The rights that the wife deserves for becomes warranty for the her life after the divorce in which she used to get it from her husband before the divorce took place; (3) The pronouncement of talā $q$ divorce verdict means the granting of husband's desire for divorce so that he needs to provide justice for her wife by giving her rights through judges' ex officio right; (4) The fulfillment of a wife's right is a mandate of LAW in article 41 (c) UU number 1/1974 and article 149 (A and B) KHI; (5) The husbands have financial ability to carry out his obligations. ${ }^{46}$

These all imply that in Magelang Religious Court, PERMA Number 03 of 2017 has already been well-implemented. It is quite reasonable because Magelang RC have become the pilot project for

${ }^{46}$ Thariq, "Hak Ex Officio Hakim: Pertimbangan Hukum Hakim terhadap Pembebanan Nafkah Iddah dan Mut'ah dalam Perkara Cerai Talak Verstek Perspektif Maqashid Syariah (Kasus di Pengadilan Agama Kabupaten Malang)," 9. 
gender, rights of children and wives mainstreaming between Kalijaga Institute for Justice (KIJ) and Indonesian Supreme Court Badilag. ${ }^{47}$

Among the indicators of this sensitivity are dignity and respect for parties which suffer most due to the divorce, namely wives and children. This is clear from verdicts which grant what they deserve in the form of 'iddah living, mut' ah and child's living. Most importantly, the verdict, either in talāq divorce or lawsuit divorce, brings the value of legal certainty or gives benefits as well as justice to the wife. Instead of putting her in uncertain condition, wifes and children get benefits by earning 'iddah living, mut'ah and child's living. This is in accordance with the legal objectives namely justice, benefit, and legal certainty although these three things are difficult to implement simultaneously altogether.

In line with that, Alef explained that the judges should compromise all three objectives proportionally although in the end, only one element is chosen and prioritized in each verdict as it so very difficult to accommodate them altogether. ${ }^{48}$ In this case, Mukti Arto asserted that the legal certainty must be enforced in all cases as each verdict must result in legal certainty. Conversely, justice concept in different cases has its own characteristic because there must be a balance among the parties and there is no exact same case among one another. ${ }^{49}$

Because of the differences among one case and another, the principle of priority should be well adjusted to the type of the case. This means that the justice is not necessarily the first priority. In some cases, priority can be given to legal certainty then followed by justice

\footnotetext{
${ }^{47}$ www / / http:pa-magelang.go.id. (Online) accessed on June 2019.

48"Hermeneutika Hukum Sebagai Alternatif Metode Penemuan Hukum Bagi Hakim Untuk Menunjang Keadilan Gender | Rahmah | Jurnal Dinamika Hukum," 303, accessed November 23, 2019, http://dinamikahukum.fh.unsoed.ac.id/index.php/JDH/article/view/211.

${ }^{49}$ Mukti Arto, "Het Beleid Van De Recheer dan Upaya Penegakan Undangundang Penghapusan Kekerasan Dalam Rumah Tangga Oleh Hakim di Lingkungan Peradilan https://badilag.mahkamahagung.go.id/artikel/publikasi/artikel/ HetBeleid-Van-De-Recheer-dan-Upaya-Penegakan-Undang-undangPenghapusan-Kekerasan-Dalam-Rumah-Tangga-Oleh-Hakim-diLingkungan-Peradilan-Agama. (Online) Retrieved on Agustus 14, 2019.
} 
and benefit. In the case of divorce, this seems to be more appropriate. The pronouncement of the divorce verdict enables the wife to gain divorce certificate as well as obtaining legal certainty. Next on, as soon as the wife and the child get their rights, it means that the verdict gives value of legal certainty, justice and benefits for them both.

Furthermore, Mukti Arto asserted that the legal certainty is in the category of wad'i law which regulates the relationship between individuals. The legal breakthrough is not possible to formulate on this domain. Meanwhile, the justice is in the scope of taklifi law which regulates the rights and obligations between individuals in civil territory. In this realm, the judge can do ijtihād to produce a justice based verdict. 50

Meanwhile, in the case of Samarinda Religious Court, some of its talāq divorce verdicts accommodated the rights of wives and children through reconvention. However, there found no verdict of taläq divorce in 2017 and 2018 with ex officio rights among the taken samples on this research, both pronounced in verstek and the presence of parties. Based on this, it can be said that PERMA Number 03 of 2017 was still not fully implemented in talāq divorce cases in Samarinda RC during 2017 and 2018. Not all verdicts are worth justice and beneficial for wives and children, as can be seen in the verdict Number 429/PDT. G/2018/PA. Smd. and Number 1843/Pdt. G/2018/PA. Smd. In fact, the mandate of article 2 PERMA obliges judges in the adjudication of women to produce a verdict that is worth justice, certainty, and benefit. In addition, they should be able to tell wives about their rights when they are litigated so that those who do not understand their rights might get access to obtain them.

On the contrary, for two talä $q$ divorce verdicts (Number 194/PDT. G/2019/PA. SMD and Number 371/PDT. G/2019/PA. SMD) during 2019 which were pronounced in verstek, wives and child got their rights through ex officio rights consisting of 'iddah living, mut'ah and child's living. The use of ex officio right in those two verdicts were based on these following considerations; (1) The wives were proven not doing nushüz, (2) Article 41 ACT Number 01 of 1974 mentioned that in case of divorce, the Court may oblige the husband to provide a living to his wife while article $149 \mathrm{KHI}$ (b) stated that due

${ }^{50}$ Mukti Arto, “Het Beleid... 
to divorce, a wife deserves for mut'ah and 'iddah living except in the condition when she is still virgin (3) The verdicts were based on plaintiffs' financial ability, and (4) The jurisprudence of MA Number 608K/AG/2003 dated on March 25, 2003 and Number $280 \mathrm{~K} / \mathrm{AG} / 2004$, dated on November 10, 2004, which regulate the range of number of $m u t$ ' ah and 'iddah. 51

Those two examined taläq divorce verdicts certainly shows considerable gender sensitivity because wives and children were entitled to their rights through the ex officio right of the judges, even though it was not proposed. This means that PERMA Number 03 of 2017 began to get well implemented because the rights of wives and children have been well-accommodated with judges' ex officio right. Accordingly, the verdict was not only worth the legal certainty, but also contains justice and benefit. The copy of the verdict also showed how the judges attempted to lead the plaintiff to fulfill his obligation by granting the wives and children's rights.

Unfortunately, for divorce lawsuit during 2017 to 2019, samples of the verdicts did not show concern on the rights of wife and children both in verstek form and otherwise. The right of wife and child is only given when being asked by the wives as litigants. The judges rarely used their ex officio right even though the wives were not doing nushuz while the husband could afford the right.

In addition, the mediator did not play his role maximally by not producing any agreement between the parties who dispute each others. The presence of the parties should be utilized by the mediator to play the role well, mainly to make them understand about their rights and obligations in the event of divorce. At least, the mediator needs to faciliate in order the parties in dispute can create an agreement that accommodates the rights and obligations of each. However, a copy of existing verdict showed that mediation did not result in any agreement that accommodates the vulnerable party. It means that the mediator was less able to play the role optimally in giving the rights of wives and children after divorce.

This means that judges' gender sensitivity was still poor. The divorce verdicts only contained legal certainty; while the justice for the wife who filed the suit and was hurt either by knowing

${ }^{51}$ See the copy of verstek No. 371/Pdt.G/2019/PA.SMD, 9. 
herhusband had affair with another woman or neglected her has not been enforced. In fact, the purpose of law should at least contain the value of justice, certainty and benefit.

From the gender perspective, the verdicts of divorce lawsuit from 2017 to 2019 have not shown concern towards the wives and children. In fact, article 2 PERMA Number 3/2017 explained that the principle of judges in the adjudication of women dealing with the law consists of gender equality, equality in the face of law, justice, benefit and legal certainty. This is valid for women who become litigants (chapters 2 and 3 PERMA). In addition, in assuring the enforcement of gender justice, judges had to explore the legal values, local wisdom and the value of justice in the community (Article 6 letter $\mathrm{C}$ ). They are also expected to convey to the women regarding their rights in certain particular cases. (Article 8 paragraph 2 PERMA Number 03 of 2017).

As a consequence, the sample verdicts of divorce lawsuit from 2017 to 2019 at Samarinda RC showed that no one has fulfilled the rights of wives, either by verstek or the presence of the parties. This means that PERMA Number 03 of 2017 has not been implemented properly as it is only worth the legal certainty. There is no significant differences on the acquisition of the rights of the wife and child after divorce by the existence of PERMA as clear from the comparison between verdicts in 2017 before the PERMA and the verdicts in 2018 and 2019 after the PERMA.

\section{Conclusion}

The study comes to these following conclusions. First, both talāq divorce and divorce lawsuit verdicts in Magelang RC during 20172019 already show excellent gender sensitivity. On the contrary, for Samarinda RC, the condition was otherwise during 2017-2018 although there found a little improvement on gender sensitivity in talāq divorce verdicts issued in 2019. Accordingly, the verdicts of lawsuit divorce from 2017 to 2019 at Samarinda RC had not shown good gender sensitivity. This is in line with the implementation of PERMA Number 03 of 2017 in those two Religious Court units. It was well implemented in Magelang RC and went otherwise in Samarinda $\mathrm{RC}$ as there is no significant differences between verdict issued before the issuence of PERMA and those which came afterward. 


\section{Bibliography}

Andaryuni, Lilik. "Pemahaman Gender Dan Tingginya Angka Cerai Gugat Di Pengadilan Agama Samarinda." Fenomena 9, no. 2 (December 1, 2017) https:/ / doi.org/10.21093/fj.v9i2.946.

Abd. Moqsith Ghazali. Kumpulan Referensi Standar Evaluasi Hakim Dalam Menerapkan Sensitivitas Jender Di Mahkamah Syar'iyah Aceh, 2009. / / digilib.stital.ac.id/index.php?p=show_detail\&id=66.

Darmodiharjo, Darji and Shidarta. Pokok-pokok Filsafat Hukum: Apa dan Bagaimana Filsafat Hukum Indonesia. Gramedia Pustaka Utama, 1995.

Dzuhayatin, Siti Ruhaini and Mochamad Sodik. "Pedoman Modeling Institusionalisasi Proses Peradilan Responsif Gender, Hak Perempuan, Dan Hak Anak Di Pengadilan Agama," n.d.,

Fakrulloh, Zudan Arif. "Penegakan Hukum Sebagai Peluang Menciptakan Keadilan," 2005. http://publikasiilmiah.ums.ac.id/handle/11617/1034.

Harahap, M. Yahya. Hukum Acara Perdata: Tentang Gugatan, Persidangan, Penyitaan, Pembuktian, dan Putusan Pengadilan. Sinar Grafika, 2005.

Hasanah, Defi Uswatun. "Hak-Hak Perempuan dalam Putusan Pengadilan Agama (Studi Perbandingan Hukum Keluarga Islam dan Konvensi CEDAW)," 2017. http:/ / repository.uinjkt.ac.id/dspace/handle/123456789/38598 . "Hermeneutika Hukum Sebagai Alternatif Metode Penemuan Hukum Bagi Hakim Untuk Menunjang Keadilan Gender | Rahmah | Jurnal Dinamika Hukum." Accessed November 23, 2019.

http://dinamikahukum.fh.unsoed.ac.id/index.php/JDH/articl e/view/211.

Hikmatiar, Erwin. "Nafkah Iddah Pada Perkara Cerai Gugat." SALAM: Jurnal Sosial dan Budaya Syar'i 3, no. 2 (September 9, 2016). https:// doi.org/10.15408/sjsbs.v3i1.3316.

Ibrahim AR, Ibrahim AR, and Nasrullah Nasrullah. "Eksistensi Hak Ex Officio Hakim dalam Perkara Cerai TTalāq." SAMARAH: Jurnal Hukum Keluarga dan Hukum Islam 1, no. 2 (December 30, 2017): 459. https://doi.org/10.22373/sjhk.v1i2.2378. 
Irianto, Sulistyowati, and Lim Sing Meij. "Praktik Penegakan Hukum: Arena Penelitian Sosiolegal Yang Kaya," n.d.

Jalaludin, Ahmad. "Budaya Hukum Bias Gender Hakim Pengadilan Agama Dalam Perkara Cerai Țalāq." Muwazah 7 (December 2015): 97-210.

Jamillah, Hj. "Judges According To Islamic Law and Indonesian Law In Islamic Court." IOSR Journal of Humanities and Social Science 22, no. 01 (January 2017): 87-93. https:// doi.org/10.9790/08372201068793.

"Kamus Hukum - R. Subekti, R. Tjitrosoedibio - Google Buku." Accessed November 23, 2019. https:// books.google.co.id/books?id=joaUPwAACAAJ\&dq=Su bekti+dan+R.Tjitrosossedibio,+Kamus + Hukum\&hl=id\&sa $=X \& v$ ed=0ahUKEwj_yt_PuYDmAhWxwzgGHe8oCk0Q6AEIKzAA.

Kodir, Faqihuddin Abdul and Ummu Azizah Mukarnawati. Referensi bagi Hakim Peradilan Agama tentang Kekerasan dalam Rumah Tangga. Komnas Perempuan, 2008. "Kontekstualisasi Hukum Berperspektif Perempuan di Peradilan Agama | Asni | Al'Adl." Accessed November 23, 2019. http:/ / ejournal.iainkendari.ac.id/al-adl/article/view/675.

Luhulima, Achie S., A. D. Kusumaningtyas, Anita Rahman, Anis Hamim, Brahmanie Hastawati, Debu Batara Lubis, Djaka Soehendera, et al. Perempuan dan Hukum: Menuju Hukum yang Berperspektif Kesetaraan dan Keadilan. Yayasan Pustaka Obor Indonesia, 2008.

Mansari, Mansari and Moriyanti Moriyanti. "Sensitivitas Hakim Terhadap Perlindungan Nafkah Isteri Pasca Perceraian." Gender Equality: International Journal of Child and Gender Studies 5, no. 1 (October 14, 2019): 43. https://doi.org/10.22373/equality.v5i1.5377. "Melihat Tren Perceraian dan Dominasi Penyebabnya - Hukumonline.Com." Accessed December 9, 2019. https://www.hukumonline.com/berita/baca/lt5b1fb923cb04f/ melihat-tren-perceraian-dan-dominasi-penyebabnya/.Achmad Ali. Menguak Tabir Hukum: Ed.2. Kencana, 2015. Pelajar, Pustaka. "Pembaruan Hukum Islam Melalui Putusan Hakim Pustaka Pelajar." Accessed November 23, 2019. 
https:/ / pustakapelajar.co.id/buku/pembaruan-hukum-islammelalui-putusan-hakim/.

Rahmah, Alef Musyahadah, Noor Asik, and Wismaningsih Wismaningsih. "Perspektif Dan Sikap Hakim Dalam Memutus Perksara Mut'ah Dan Nafkah Iddah Di Pengadilan Agama Purwokerto, Banyumas, Purbalingga." Prosiding 7, no. 1 (November 30, 2017). http://jurnal.lppm.unsoed.ac.id/ojs/index.php/Prosiding/arti cle/view/493.

Rasyid, Roihan A. Hukum Acara Peradilan Agama. Raja Grafindo Persada, 1991.

Riadi, Edi. "Dinamika Putusan Mahkamah Agung Republik Indonesia dalam Bidang Perdata Islam," 2011.

Soekanto, Soerjono. Kesadaran Hukum \& Kepatuhan Hukum: Suatu Percobaan Penerapan Metode Yuridis-Empiris untuk Mengukur Kesadaran Hukum dan Kepatuhan Hukum Mahasiswa Hukum terhadap Peraturan Lalu Lintas. Rajawali, 1982.

Syamsudin, M. "Keadilan Prosedural Dan Substantif Dalam Putusan Sengketa Tanah Magersari." Jurnal Yudisial 7, no. 1 (March 24, 2014): 18-33. https://doi.org/10.29123/jy.v7i1.91.

Thariq, Muhammad Aqwam. "Hak Ex Officio Hakim: Pertimbangan Hukum Hakim terhadap Pembebanan Nafkah Iddah dan Mut'ah dalam Perkara Cerai Țalāq Verstek Perspektif Maqashid Syariah (Kasus di Pengadilan Agama Kabupaten Malang)," n.d.,

Tolhah, Abu. "Peluang Dan Tantangan Kompetensi Peradilan Agama Pasca Amandemen Undang-Undang Nomor 7 Tahun 1989 Tentang Peradilan Agama." Asy-Syari'ah 18, no. 1 (August 31, 2015). https:/ / doi.org/10.15575/as.v18i1.654.

Yuni, Lilik Andar. "Kompatibilitas KHI Dengan Konvensi Perempuan | Yuni | Mimbar Hukum - Fakultas Hukum Universitas Gadjah Mada." Mimbar Hukum 22, no. 1 (2010). 